DOI: $10.1515 / \mathrm{rpp}-2015-0051$

Doctor of Pedagogical Sciences, Professor, OLENA ZHYZHKO

Universidad Autónoma de Zacatecas, México Address: Torre de Posgrados II, Av. Preparatoria, s/n, Fracc. Progreso, Zacatecas, Zac., 98000, Mexico

E-mail: eanatoli@yahoo.com

\title{
POSTGRADUATE PROFESSIONAL PEDAGOGICAL EDUCATION IN MEXICO
}

\begin{abstract}
This article is the result of scientific comparative-pedagogical research, which purpose was to highlight the main features of postgraduate professional pedagogical education in Mexico. The author found that the postgraduate professional pedagogical education in Mexico is performed by public and private higher education institutions: higher pedagogical schools, universities, autonomous universities, tecnological universities, technological institutes, research institutions, institutions of postgraduate education. Despite common goals, public and private institutions performed the posgraduate profesional pedagogical education on various organizational and procedural schemes. The main characteristics of postgraduate professional pedagogical education in Mexico are a relatively recent launch of the first programs (70-ies of the twentieth century); the rapid development of postgraduate professional pedagogical education in the 80-ies - 90-ies years of the XX century; the relative uniformity of its distribution between the state $(61.1 \%)$ and private $(39.9 \%)$ universities; careful surveillance of public higher pedagogical education quality through periodic programs's evaluation; various thematic orientation of the programs; low rates of the ultimate effectiveness (the number of graduates, who received a diploma).

Key words: postgraduate professional pedagogical education, Mexico's education system, State policy in the field of postgraduate education, public and private universities that offer postgraduate professional pedagogical education.
\end{abstract}

\section{INTRODUCTION}

In the new historical conditions of globalization, the new guidelines to the study of pedagogical experience abroad are emerging, and the new approaches are being developed (Germany, Italy, Spain, Turkey, USA, China, France, Great Britain and others). The analysis of sources showed that over the past decades, domestic scientists actively realized comparative studies in the field of professional education (N. Bidyuk, T. Chuvakova, T. Desiatov, A. Kaplun, T. Koshmanova, I. Kovchyna, V. Kudin, N. Lavrychenko, M. Leshenko, O. Lokshina, O. Matvienko, N. Mukan, N. Nychkalo, O. Ogienko, L. Pukhovska, A. Sbruieva, N. Seyko, O. Zabolotna and others).

We believe that research of organizing experience of the postgraduate professional pedagogical education in Mexico will help create original national educational structure that would meet the national traditions and, at the same time, be absorbed in everything new that worked out in recent decades in this country.

It is necessary to note that postgraduate professional pedagogical education (Spanish: los estudios de posgrado en educación) in Mexico started in 70-ies of XX century with the opening of the first specialty and Master programs in pedagogy of the National Autonomous University of Mexico (Universidad Nacional Autónoma de México - UNAM), as well as the 
creation of the National Council of Science and Technology (Consejo Nacional de Ciencia y Tecnología - CONACYT).

In order to provide non-formal pedagogic education for own faculty teacher, in 1970 at the National Autonomous University of Mexico Didactic Center (Centro de Didáctica) and Department of new teaching methods (Comisión de Nuevos Métodos) were opened, and in 1975-1977 a program of the specialty "Pedagogy of high school" (Programa de Especialización para la Docencia) was launched; in the late 70-ies appeared Master Programs "Education sciences" and "Pedagogics of higher school" (Esquivel, 1996).

Generally, in the 70-ies of the XX century, continuing education (specialization, Master and Doctorate) in Mexico was provided in 226 programs of 13 universities, all its acquired 5,763 students ( $2.6 \%$ of all students of higher education of the country). However, already in the 80 -th of the XX century, the number of postgraduate students has increased by five times (42,654 students), and the number of universities have suggested by seven times (152 universities and 1,604 programs). In the 90-th of the XX this trend continued (Ezpeleta, Sánchez, 1982).

It should be noted that such reckless and unplanned growth of specialties, Master and Doctoral programs in general and especially regarding pedagogic education in the 80-ies 90 -ies of the XX century, explained the new requirements for university teachers, who must have at least a Master's degree in order to work in the Bachelor's programs. However, the emergence of so many programs of postgraduate education does not always ensure their quality, so in 1991 the National Council of Science and Technology was established the list of the high quality postgraduate programs (Padrón de Posgrados de Excelencia), which contain only departments which were evaluated by special Assessment experts of the Ministry of Education and the development of which is allocated a special state funding (Moreno, 2003).

Some evaluation criteria were the number of teachers with doctorate scientific degree and membership in the National Scientific Researchers (Sistema Nacional de Investigadores $\mathrm{SNI}$ ); the number of complete and incomplete teaching rates; number of research groups registered with the Ministry of Education, and the level of their scientific performance, the number of graduates who received a diploma.

It is important to explain that in the educational system in Mexico, there are two documents that guarantee higher or postgraduate education: certificate with the list of items and assessments (certificado) and diploma (título). Usually in hiring is only certificate required, for this reason most graduates do not issue a diploma. Thus, the accreditation of universities has two options: the number of graduates and the number of graduates who received a diploma.

\section{THE AIM OF THE STUDY}

The aim of the comparative scientific-pedagogical research, which results are presented in this article, was to highlight the main features of postgraduate professional pedagogical education in Mexico.

\section{THEORETICAL FRAMEWORK AND RESEARCH METHODS}

The definition of advantages and features of postgraduate professional pedagogical education in Mexico requires the use of comparative pedagogy methods (N. Bidyuk, T. Desiatov, N. Nychkalo, O. Ogienko, L. Pukhovska, A. Sbruieva and others). The need of studied foreign experience to reform the national system of postgraduate professional pedagogical education is caused by the following factors:

a) socio-economic requirements of the reform of postgraduate professional pedagogical education in the context of globalization of all processes in a society based on the study and use the experience of foreign countries; 
b) the need to expand theoretical and methodological rationale for the further development of professional pedagogical education, taking into account the achievements of professional pedagogy of foreign countries;

c) deepen traditional tasks and developing new pedagogical approaches to solving problems of humanization and intellectualization of postgraduate professional pedagogical education;

d) the need to enrich the educational and organizational forms of postgraduate professional pedagogical education based on the study of foreign experience;

d) the urgent need to develop a new instrument of theoretical knowledge in the field of comparative vocational pedagogy (Ничкало, 2001).

This work was performed under the critical-dialectical approach, using research methods of analysis, synthesis, comparison and generalization that were necessary to study the original texts and official documents; organization of the studied material and its exposure.

\section{RESULTS}

The comparative pedagogical study realized by us, showed that postgraduate professional pedagogical education in Mexico has become widespread since 1984, when all pedagogical schools (Spanish: normales) have obtained university status (up to 1984 the majority of pedagogic schools provided only incomplete higher education (vocational)) and started, except incomplete higher education (vocational), to provide graduate (Bachelor) and postgraduate (Master, Doctor) education.

In addition to the state higher pedagogical schools, the development of postgraduate professional pedagogical education promoted the National Autonomous University of Mexico (Universidad Nacional Autónoma de México - UNAM), National Polytechnic Institute (Instituto Politécnico Nacional - IPN), Autonomous University of Nuevo Leon (Universidad Autónoma de Nuevo León - UANL), the Higher Institute of Education Sciences of the State of Mexico (Instituto Superior de Ciencias de la Educación del Estado de México - ISCEEM), Institute of Educational Sciences of Michoacan (Instituto Michoacano de Ciencias de la Educación - IMCED), Interdisciplinary Centre for educational research and technology in education of Queretaro (Centro Interdisciplinario de Investigación y Docencia Tecnológica de Querétaro - CIIDET), Autonomous University of the State of Morelos (Universidad Autónoma del Estado de Morelos UAEM), University of Guanajuato (Universidad de Guanajuato), Autonomous University of Querétaro (Universidad Autónoma de Querétaro), University of Veracruz (Universidad Veracruzana), National Pedagogical University (Universidad Pedagógica Nacional - UPN), Institute of Pedagogical Studies and Problems of Teaching of Tamaulipas (Instituto Tamaulipeco de Investigación Educativa y Desarrollo de la Docencia), Technological Institute of Monterrey (Instituto Tecnológico de Estudios Superiores de Monterrey), West Technological Institute (Instituto Tecnológico de Estudios Superiores de Occidente - ITESO), Iberoamerican University (Universidad Iberoamericana), University of Guadalajara (Universidad de Guadalajara - UdeG), Autonomous University of Zacatecas (Universidad Autónoma de Zacatecas - UAZ), University of Sonora (Universidad de Sonora), Autonomous University of Sinaloa (Universidad Autónoma de Sinaloa - UAS), Autonomous University of Durango (Universidad Autónoma de Durango - UAD) and others (Table 1).

Generally, postgraduate professional pedagogical education provided in Mexico by higher pedagogical schools of Ministry of Education, autonomous universities (a national higher education institution which is independent of the Ministry of Education but funded 
by federal and state governments) and private educational institutions. We consider further the main characteristics of postgraduate professional pedagogical education using the examples of Teacher Training Center of the Ministry of Education, Autonomous University of Zacatecas, National Pedagogical University, Technological Institute of Monterrey and the Autonomous University of Durango.

Table 1

Higher education institutions in Mexico, which offer a licentiate, Master, Doctorate in Education

\begin{tabular}{|c|c|c|}
\hline Name in Spanish & Name in English & Specialities \\
\hline $\begin{array}{l}\text { 1. La Universidad Nacional } \\
\text { Autónoma de México (UNAM) }\end{array}$ & $\begin{array}{l}\text { National Autonomous } \\
\text { University of Mexico }\end{array}$ & $\begin{array}{c}\text { "High school pedagogics", } \\
\text { "History and theory } \\
\text { of pedagogy", "Technology } \\
\text { in Education", } \\
\text { "Educational science" }\end{array}$ \\
\hline $\begin{array}{c}\text { 2. Instituto Politécnico Nacional } \\
\text { (IPN) a través del Departamento } \\
\text { de Investigación Educativa } \\
\text { (DIE) }\end{array}$ & National Polytechnic Institute & $\begin{array}{c}\text { "History and theory } \\
\text { of pedagogy", "Technology } \\
\text { in Education", "Educational } \\
\text { science", "Didactics of teaching } \\
\text { in higher education" }\end{array}$ \\
\hline $\begin{array}{l}\text { 3. Universidad Autónoma } \\
\text { de Nuevo León (UANL) }\end{array}$ & $\begin{array}{l}\text { Autonomous University } \\
\text { of Nuevo Leon }\end{array}$ & $\begin{array}{c}\text { "History and theory } \\
\text { of pedagogy", "Didactics } \\
\text { of teaching in higher education" }\end{array}$ \\
\hline $\begin{array}{c}\text { 4. Instituto Superior de Ciencias } \\
\text { de la Educación del Estado } \\
\text { de México (ISCEEM) }\end{array}$ & $\begin{array}{c}\text { Higher Institute of Education } \\
\text { Sciences of the State } \\
\text { of Mexico }\end{array}$ & $\begin{array}{c}\text { "Didactics of teaching in higher } \\
\text { education", } \\
\text { "Educational science" }\end{array}$ \\
\hline $\begin{array}{c}\text { 5. Instituto Michoacano } \\
\text { de Ciencias de la Educación } \\
\text { (IMCED) }\end{array}$ & $\begin{array}{l}\text { Institute of Educational } \\
\text { Sciences of Michoacan }\end{array}$ & $\begin{array}{c}\text { "Didactics of teaching in higher } \\
\text { education", } \\
\text { "Educational science" }\end{array}$ \\
\hline $\begin{array}{l}\text { 6. Centro Interdisciplinario } \\
\text { de Investigación y Docencia } \\
\text { Tecnológica de Querétaro } \\
\text { (CIIDET) }\end{array}$ & $\begin{array}{c}\text { Interdisciplinary Centre } \\
\text { for educational research } \\
\text { and technology in education } \\
\text { of Queretaro }\end{array}$ & $\begin{array}{l}\text { "Didactics of teaching in higher } \\
\text { education", "Technology } \\
\text { in Education" }\end{array}$ \\
\hline $\begin{array}{l}\text { 7. Universidad Autónoma del } \\
\text { Estado de Morelos (UAEM) }\end{array}$ & $\begin{array}{c}\text { Autonomous University } \\
\text { of the State of Morelos }\end{array}$ & $\begin{array}{l}\text { "Didactics of teaching } \\
\text { in higher education" }\end{array}$ \\
\hline 8. Universidad de Guanajuato & University of Guanajuato & "Educational science" \\
\hline $\begin{array}{l}\text { 9. Universidad Autónoma } \\
\text { de Querétaro }\end{array}$ & $\begin{array}{l}\text { Autonomous University } \\
\text { of Querétaro }\end{array}$ & $\begin{array}{l}\text { "Didactics of teaching in higher } \\
\text { education", } \\
\text { "Educational management" }\end{array}$ \\
\hline 10. Universidad Veracruzana & University of Veracruz & $\begin{array}{c}\text { "Didactics of teaching in higher } \\
\text { education" }\end{array}$ \\
\hline \begin{tabular}{|l|} 
11. Escuela Normal Superior de \\
Estado de Baja California Sur \\
\end{tabular} & $\begin{array}{l}\text { Higher pedagogical school } \\
\text { of State Baja California Sur }\end{array}$ & $\begin{array}{c}\text { "Didactics of teaching in } \\
\text { primary and secondary schools" }\end{array}$ \\
\hline $\begin{array}{c}\text { 12. Benemérita y Centenaria } \\
\text { Escuela Normal del Estado } \\
\text { de San Luis Potosí }\end{array}$ & $\begin{array}{l}\text { Higher pedagogical school } \\
\text { of State San Luis Potosi }\end{array}$ & $\begin{array}{c}\text { "Preschool education", "Special } \\
\text { education", "Didactics } \\
\text { of teaching in primary } \\
\text { and secondary schools" }\end{array}$ \\
\hline
\end{tabular}




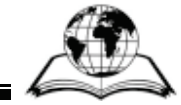

Continued

\begin{tabular}{|c|c|c|}
\hline Name in Spanish & Name in English & Specialities \\
\hline $\begin{array}{l}\text { 13. Universidad Pedagógica } \\
\text { Nacional (UPN) }\end{array}$ & $\begin{array}{l}\text { National Pedagogical } \\
\text { University }\end{array}$ & $\begin{array}{l}\text { "Gender issues in education", } \\
\text { "Didactics of teaching } \\
\text { in primary and secondary } \\
\text { schools", "Pedagogical } \\
\text { intervention" }\end{array}$ \\
\hline $\begin{array}{l}\text { 14. Instituto Tamaulipeco } \\
\text { de Investigación Educativa } \\
\text { y Desarrollo de la Docencia }\end{array}$ & $\begin{array}{l}\text { Institute of Pedagogical } \\
\text { Studies and Problems } \\
\text { of Teaching of Tamaulipas }\end{array}$ & $\begin{array}{l}\text { "Didactics of teaching in higher } \\
\text { education", "Technology } \\
\text { in Education" }\end{array}$ \\
\hline $\begin{array}{l}\text { 15. Instituto Tecnológico } \\
\text { de Estudios Superiores } \\
\text { de Monterrey (a través de su } \\
\text { Universidad virtual vía satélite } \\
\text { en todos sus campus del país) }\end{array}$ & $\begin{array}{c}\text { Technological Institute } \\
\text { of Monterrey }\end{array}$ & $\begin{array}{l}\text { "Technology in Education", } \\
\text { "Educational management", } \\
\text { "Educational innovations" } \\
\text { "Educational science" }\end{array}$ \\
\hline $\begin{array}{l}\text { 16. Instituto Tecnológico } \\
\text { de Estudios Superiores } \\
\text { de Occidente (ITESO) }\end{array}$ & West Technological Institute & $\begin{array}{l}\text { "Technology in Education", } \\
\text { "Educational management", } \\
\text { "Didactics of teaching in } \\
\text { primary and secondary schools" }\end{array}$ \\
\hline 17. Universidad Iberoamericana & Iberoamerican University & $\begin{array}{l}\text { "Technology in Education", } \\
\text { "Educational management", } \\
\text { "Educational science" }\end{array}$ \\
\hline $\begin{array}{l}\text { 18. Universidad de Guadalajara } \\
\text { (UdeG) }\end{array}$ & University of Guadalajara & $\begin{array}{c}\text { "Educational science", "History } \\
\text { and theory of pedagogy", } \\
\text { "Educational science" }\end{array}$ \\
\hline $\begin{array}{l}\text { 19. Universidad Autónoma } \\
\text { de Guadalajara (UAG) }\end{array}$ & $\begin{array}{c}\text { Autonomous University } \\
\text { of Guadalajara }\end{array}$ & $\begin{array}{c}\text { "Educational science", } \\
\text { "Didactics of teaching in higher } \\
\text { education", "Technology } \\
\text { in Education" }\end{array}$ \\
\hline $\begin{array}{l}\text { 20. Instituto de Ciencias } \\
\text { y Estudios Superiores } \\
\text { de Tamaulipas (ICEST) }\end{array}$ & $\begin{array}{l}\text { Research Institute } \\
\text { of Tamaulipas }\end{array}$ & $\begin{array}{l}\text { "Educational science", } \\
\text { "Educational management", } \\
\text { "Technology in Education" }\end{array}$ \\
\hline $\begin{array}{l}\text { 21. Universidad Autónoma } \\
\text { de Zacatecas (UAZ) }\end{array}$ & $\begin{array}{c}\text { Autonomous University } \\
\text { of Zacatecas }\end{array}$ & $\begin{array}{l}\text { "History and theory } \\
\text { of pedagogy", "Educational } \\
\text { science", "Communication } \\
\text { in education", "Teaching } \\
\text { in higher education } \\
\text { and institutional processes", } \\
\text { "Technology in Education", } \\
\text { "Educational Policy" }\end{array}$ \\
\hline 22. Universidad de Sonora & University of Sonora & $\begin{array}{l}\text { "Educational science", } \\
\text { "Educational management" }\end{array}$ \\
\hline $\begin{array}{l}\text { 23. Universidad Autónoma } \\
\text { de Sinaloa (UAS) }\end{array}$ & $\begin{array}{c}\text { Autonomous University } \\
\text { of Sinaloa }\end{array}$ & "Educational science" \\
\hline 24. Normales superiores & $\begin{array}{l}\text { Public higher pedagogical } \\
\text { schools }\end{array}$ & $\begin{array}{l}\text { "Preschool education", "Special } \\
\text { education", "Didactics } \\
\text { of teaching in primary } \\
\text { and secondary schools" }\end{array}$ \\
\hline
\end{tabular}




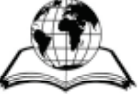

\begin{tabular}{|c|c|c|}
\hline Name in Spanish & Name in English & Specialities \\
\hline $\begin{array}{l}\text { 5. Centros de Actualización de } \\
\text { Magisterio (CAM) de la SEP }\end{array}$ & $\begin{array}{c}\text { Teacher training centers } \\
\text { of the Ministry of Education } \\
\text { of Mexico }\end{array}$ & $\begin{array}{c}\text { "Preschool education", "Special } \\
\text { education", "Didactics } \\
\text { of teaching in primary } \\
\text { and secondary schools" }\end{array}$ \\
\hline $\begin{array}{l}\text { 26. Universidad Autónoma } \\
\text { de Durango (UAD) }\end{array}$ & $\begin{array}{c}\text { Autonomous University } \\
\text { of Durango }\end{array}$ & $\begin{array}{c}\text { "Educational innovations" } \\
\text { "Technology in Education", } \\
\text { "Educational science", } \\
\text { "Didactics of teaching in } \\
\text { primary and secondary schools" }\end{array}$ \\
\hline $\begin{array}{l}\text { 27. Universidad Interamericana } \\
\text { para el Desarrollo (UNID) }\end{array}$ & $\begin{array}{c}\text { Inter-American University } \\
\text { of Development }\end{array}$ & $\begin{array}{l}\text { "Educational innovations", } \\
\text { "Technology in Education", } \\
\text { "Educational management" }\end{array}$ \\
\hline $\begin{array}{l}\text { 28. Escuela Superior } \\
\text { de Pedagogía (ESP) }\end{array}$ & Higher school of Pedagogy & $\begin{array}{l}\text { "Preschool education", "Special } \\
\text { education", "Didactics } \\
\text { of teaching in primary } \\
\text { and secondary schools" }\end{array}$ \\
\hline $\begin{array}{l}\text { 29. Instituto de Ciencias, } \\
\text { Humanidades y Tecnologías } \\
\text { de Guanajuato (ICYTEG) }\end{array}$ & $\begin{array}{c}\text { Institute of Science } \\
\text { and Technology } \\
\text { of Guanajuato }\end{array}$ & $\begin{array}{c}\text { "Didactics of teaching in higher } \\
\text { education", "Technology } \\
\text { in Education", "Educational } \\
\text { management" }\end{array}$ \\
\hline $\begin{array}{l}\text { 30. Instituto de Ciencias, } \\
\text { Humanidades y Tecnologías } \\
\text { de Zacatecas (ICYTEZ) }\end{array}$ & $\begin{array}{l}\text { Institute of Science } \\
\text { and Technology } \\
\text { of Zacatecas }\end{array}$ & $\begin{array}{l}\text { "Educational innovations", } \\
\text { "Technology in Education" }\end{array}$ \\
\hline $\begin{array}{l}\text { 31. Instituto Mexicano de } \\
\text { Estudios Pedagógicos A.C. } \\
\text { (IMEP) }\end{array}$ & $\begin{array}{c}\text { Mexican Institute } \\
\text { of Pedagogical Studies }\end{array}$ & "Pedagogical methods" \\
\hline $\begin{array}{l}\text { 32. Escuela Normal Superior } \\
\text { de Ciudad Madero, } \\
\text { A. C. (ENSCd.M) }\end{array}$ & $\begin{array}{c}\text { Higher pedagogical school } \\
\text { of Ciudad Madero }\end{array}$ & $\begin{array}{c}\text { "Preschool education", "Special } \\
\text { education", "Didactics } \\
\text { of teaching in primary } \\
\text { and secondary schools" }\end{array}$ \\
\hline $\begin{array}{l}\text { 33. Universidad Pedagógica } \\
\text { de Durango }\end{array}$ & $\begin{array}{l}\text { Pedagogical University } \\
\text { of Durango }\end{array}$ & $\begin{array}{l}\text { "Preschool education", "Special } \\
\text { education", "Didactics } \\
\text { of teaching in primary } \\
\text { and secondary schools" }\end{array}$ \\
\hline
\end{tabular}

Source: developed by the author on a study of curricula of Mexican Universities.

The study of the official documents of the Mexican Ministry of Education showed that the main purpose of postgraduate professional pedagogical education is considered to be theoretical, methodological, scientific training of teaching staff of various educational levels (SEP, 2012).

It is important to note, that postgraduate professional pedagogical education is part of higher education system, after which take care the State Planning Commission of Higher Education (Comisión Estatal de Planeasión de la Educación Superior - COEPES), National Planning Commission of Higher Education (Comisión Nacional de Planeasión de la Educación Superior - CONPES) and the National Planning permanent system of higher education (Sistema Nacional de Planeasión Permanente de la Educación Superior - SINAPPES). 
Higher education institutions should undergo the evaluation by Accreditation Council of Higher Education (Consejo para la Acreditación de la Educación Superior - COPAES), after which they are funded by Investment Fund for Accredited Programs (Fondo de Inversión para Programas Evaluados in Acreditados - FIUPEA). Evaluation of the quality of education in universities carried Interinstitutional Evaluation Committee for Higher Education (Comités Interinstitucionales de Evaluación de la Educación Superior - CIEES) and the National Center for the Evaluation of Higher Education (Centro Nacional de Evaluación para la Educación Superior - CENEVAL) (Villa, 2003).

The $71.1 \%$ of the total (more than 5300) of public and private institutions of different typological profiles (universities, autonomous universities, tecnological universities, technological institutes, research institutions, institutions of postgraduate education, higher pedagogical schools) of Mexico's higher education system prepare masters, and only 7\% doctors (ANUIES, 2015).

It is important to pay attention, that, despite common goals, public and private institutions performed the posgraduate profesional pedagogical education on various organizational and procedural schemes. Moreover, among the state universities, there are also significant differences. Thus, the postgraduate programs of higher pedagogical schools of the Ministry of Education (one of which is the Centre for Teacher Training of Ministry of Education) and the National Pedagogical University focused exclusively on didactical problems of teaching, while postgraduate pedagogical education provided in autonomous universities (one of which is the Autonomous University of Zacatecas), have a sociopedagogical orientation (Arredondo, Pérez, Morán, 2006) (Table 1).

Analysis of the programs of the Autonomous University of Zacatecas shows that one of the main directions of their research projects is a critical analysis of existing educational models and address the challenges of teaching in socio-critical perspective.

However, despite these differences, Teacher Training Center of the Ministry of Education, the National Pedagogical University and the Autonomous University of Zacatecas have high requirements to their undergraduate and graduate students. In postgraduate educational programs of these institutions, research work occupies an important place (40-60\% of the curriculum), and the thesis is a prerequisite for graduation. At the same time, to obtain a Master's degree in private universities (Technological Institute of Monterrey, Autonomous University of Durango and others) is not always necessary to conduct research and defend scientific work; the students can just pass a professional exam, in some cases it is enough to get a certain amount credits.

However, the high quality of postgraduate education, providing by public universities, does not ensure its ultimate effectiveness (the statistics on the number of graduates, who received a diploma). Thus, in 2009 of the total number of 256 graduates in Pedagogy of the three investigated institutions (Teacher Training Centre of the Ministry of Education, the National Pedagogical University and the Autonomous University of Zacatecas), only 99 students received a diploma (38.67\%), and of the total number of 342 graduates in Master in Education, only 159 people (46.49\%). The worst performance was in the Autonomous University of Zacatecas - $2.59 \%$ (Table 2) (Villarreal, Calderón, 2009).

It should be noted that $39.9 \%$ of all universities offering postgraduate pedagogical education in Mexico are private, of which are considered leading the Institute of Technology of Monterrey, Iberoamerican University, the Autonomous University of Guadalajara, Autonomous University of Durango, Inter-American Development University, Institute of Science and Technology of Zacatecas, Mexican Institute of Pedagogical Studies and others. 


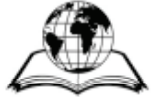

Table 2

Indicators of number of graduates of public universities (using examples of the three institutions), who received a diploma of Postgraduate Education

\begin{tabular}{|c|c|c|c|c|c|c|}
\hline \multirow{3}{*}{ Institutions } & \multicolumn{5}{|c|}{ Programs } \\
\cline { 2 - 7 } & $\begin{array}{c}\text { Sumber } \\
\text { of } \\
\text { graduates } \\
\text { of graduates, } \\
\text { who received } \\
\text { a diploma } \\
\text { of Postgraduate } \\
\text { Education }\end{array}$ & $\begin{array}{c}\text { Number } \\
\text { Edumber }\end{array}$ & $\begin{array}{c}\text { Number } \\
\text { of } \\
\text { graduates } \\
\text { of graduates, } \\
\text { who received } \\
\text { a diploma } \\
\text { of Postgraduate } \\
\text { Education }\end{array}$ & $\%$ \\
\hline $\begin{array}{c}\text { Autonomous } \\
\text { University } \\
\text { of Zacatecas }\end{array}$ & 256 & 99 & 38.67 & 212 & 2 & 2.59 \\
\hline $\begin{array}{c}\text { National } \\
\text { Pedagogical } \\
\text { University }\end{array}$ & & & 77 & 55 & 25.94 \\
\hline $\begin{array}{c}\text { Teacher } \\
\text { Training } \\
\text { Centre of the } \\
\text { Ministry } \\
\text { of Education }\end{array}$ & & & & 130 & 104 & 80.00 \\
\hline Total & 256 & 99 & 38.67 & 342 & 159 & 46.49 \\
\hline
\end{tabular}

Source: Villarreal Veloz, J., Calderón López Velarde, J. (2009). Los Posgrados en Educación en Zacatecas: Masificación y Anarquía, Zacatecas, UPN.

Mandatory requirement of the Ministry of Education for the recognition of Specialists's, Masters's and Doctors's diplomas, that give these institutions to their graduates (in the Mexican education system gives each university not only Bachelors's, specialists's and masters's diplomas as it is in the educational system of Ukraine, but also Doctors's diplomas), are signing separate agreements (Acuerdo 279), passing the accreditation and receiving the authorization to provide postgraduate pedagogical education. In addition, the recognized private higher education institutions must be members of the Mexican Federation of Private Higher Educational Institutions (Federación de Instituciones Mexicanas Particulares de Educación Superior - FIMPES) and undergo the additional accreditation by this organization (Villa, 2003; Rubio, 2011).

Regarding the thematic focus of programs, we found, that in public higher pedagogical schools (such as Teacher Training Center of the Ministry of Education) and pedagogical universities (National Pedagogical University) mainly prevail following specialities: "Preschool education", "Special education", "Didactics of teaching in primary and secondary schools", "Pedagogical intervention","Gender issues in education", while in autonomous universities (Autonomous University of Zacatecas and others) there are offered "History and theory of pedagogy", "Didactics of teaching in higher education", "Educational science", "Communication in education", "Teaching in higher education and institutional processes", "Education policy", and in private universities there are mostly proposed "Educational management", "Educational innovations" and "Technology in education" (Table 1). 


\section{CONCLUSIONS}

Therefore, on the basis of comparative pedagogical analysis we have identified the following main features of postgraduate pedagogical education in Mexico: a relatively recent launch of the first programs (70-ies of the twentieth century); the rapid development of postgraduate professional pedagogical education in the 80 -ies - 90 -ies years of the XX century; the relative uniformity of its distribution between the state $(61.1 \%)$ and private $(39.9 \%)$ universities; careful surveillance of public higher pedagogical education quality through periodic programs's evaluation; various thematic orientation of the programs; low rates of the ultimate effectiveness (the number of graduates, who received a diploma).

The prospects for further studies about postgraduate professional pedagogical education in Mexico can be the study of its formation and development, analysis of conceptual, organizational and legal principles of its functioning, its legal bases, the principles of its governance, its structural and procedural components, etc.

\section{REFERENCES}

1. ANUIES. (2015). Estadísticas de la Educación Superior [Higher Education Statistics]. Retrieved 9.07.2015 from : http://www.anuies.mx/servicios/e_educacion/index2.php.

2. Galván, V., Pérez Rivera, G., Morán Oviedo, P. (2006). Políticas del Posgrado en México [Postgraduate Education Policy in Mexico]. Retrieved 26.12.2015 from : http://reencuentro.xoc.uam.mx/no45/index.html\# ftn1.

3. Esquivel Larrondo, J. (1996). La idea del posgrado en la nueva universidad. Universidad y sociedad la inminencia del cambio [The Concept of Postgraduate Education in a New University. Need for Change in University and Society]. Pensamiento universitario [University Thought], CESU, UNAM, pp. 46-60 (in Spanish).

4. Ezpeleta, J., Sánchez, M. (1982). En busca de la realidad educativa: maestrías en educación en México [In Search for Educational Reality: Masters in Education in Mexico]. México : DIE-CONACYT, 189 p. (in Spanish).

5. Moreno Bayardo, M. (2003). Procesos de formación en educación superior. Los retos para el posgrado [The Process of Higher Education Forming. Challenges for Postgraduate Education ]. La Universidad hoy [The University Today], pp. 157-172 (in Spanish).

6. Rubio Oca, J. (coordinador). (2011). La politica educativa y la educación superior en México [Policy of Education and Higher Education in Mexico]. Retrieved 15.06.2015 from : http://ses4.sep.gob.mx.

7. SEP. (2012). Programa Sectorial de Educación 2012-2018 [Education Programs for 2012-2018]. México, SEP, 60 p. (in Spanish).

8. Villa Lever, L. (2003). La educación superior en México, entre lo público y lo privado [State and Private Higher Education in Mexico]. Ponencia presentada en el XVII Congreso Nacional de Posgrado, 27 de octubre de 2003, Aguascalientes, Ags. México (in Spanish).

9. Villarreal Veloz, J., Calderón López Velarde, J. (2009). Los Posgrados en Educación en Zacatecas: Masificación y Anarquía, Zacatecas [Postgraduate Education in Zacatecas:Overcrowding and Anarchy], UPN, 10 p. (in Spanish).

10. Ничкало, Н. (2001). Теоретико-методологічні проблеми і перспективи досліджень з неперервної професійної освіти [Theoretical and Methodological Problems and Prospects of Research on Continuous Professional Education]. Hеперервна професійна освіта: теорія і практика : зб. наук. пр. АПН Украйни, Ін-т педагогіки і психології проф. освіти [Continuing professional education: Theory and Practice], pp. 35-41 (in Ukrainian). 